\author{
International Journal of Innovative Research in \\ Electrical, Electronics, Instrumentation and Control Engineering
}

Vol. 8, Issue 7, July 2020

\title{
Parametric Design of Height and Weight Measuring System
}

\author{
Tunji John Erinle1, Dayo Hephzibah Oladebeye ${ }^{2}$, Ibrahim Bunmi Ademiloye ${ }^{3}$ \\ Lecturer, Mechanical Engineering, The Federal Polytechnic, Ado-Ekiti, Nigeria ${ }^{1}$ \\ Chief Lecturer, Mechanical Engineering, The Federal Polytechnic, Ado-Ekiti, Nigeria ${ }^{2}$ \\ Principal Technologist, Electrical \& Electronic Engineering, The Federal Polytechnic, Ado-Ekiti, Nigeria ${ }^{3}$
}

\begin{abstract}
Anthropometry medical measuring system is very important in health sector in taking the physical measurement of patients. The research focused on the need to consider a parametric design of height and weight measuring system with the enlightenment of basic design principle. The materials involved for the parametric design of this medical measuring system under study are Load Cells with Strain Gauge (weight sensor), Sonar with Ultrasonic Sensors (height sensor), Liquid Crystal Display, Medium Density Fibreboard, Rubber Mounting, Microcontroller Arduino Board and other important accessories. The results from the design analysis revealed that the system weight sensor platform has shear force of $630 \mathrm{~N}$, maximum bending moment of $126 \mathrm{Nm}$. The compressive stress that could be induced during measurement of maximum human weight is $6 \mathrm{kN} / \mathrm{m}^{2}$ and stress that could be induced due to maximum bending moment is amount to $605 \mathrm{~N} / \mathrm{m}^{2}$. The amount by which weight sensor platform could deflect when subjected to bending moment is $0.000004 \mathrm{~m}$. These values indicate that the design is safe for operation which is far lesser than the property parameters of the materials used for the weight sensor platform. The designed height of the system for the measuring of the height is about $2.1 \mathrm{~m}$ ( 7 Feet), the area of the stand platform for the measuring of the weight is about $0.2 \mathrm{~m}^{2}$. The weight sensor for the design could measure from $1 \mathrm{~kg}$ to $200 \mathrm{~kg}$ with accuracy of about $\pm 0.1 \mathrm{~kg}$ and height measuring sensor could measure through a scanning range of 0.4 to $2.5 \mathrm{~m}$ with accuracy of about $\pm 1 \mathrm{~mm}$.
\end{abstract}

Keywords: Anthropometry, Manikin, Medical measuring system, Parametric design, Sensor.

\section{INTRODUCTION}

Design is the creation of plans with the use of scientific principles, technical information and imagination in the description of any machine or system to perform desired and specific functions with maximum economy and efficiency [1]. Design is very vital in the production of any functional system. Anthropometry is the science that deals with the application of scientific physical measurement methods of human beings for the development of engineering design standards according to Aderoba [2] cited in Udosen [3] in which bodily measurements are the mainstay of anthropological research [4]. The measurement of human height and weight is very significant to their health. Height and weight are important indicators of human health and also it could be a very essential indicator to people's health. For children, it is important to monitor that they are growing at a healthy rate and for adults it is important to monitor whether or not their height decreases [5]. Stadiometer is a device for measuring standing height which consists of a vertical ruler with a sliding horizontal board which is adjusted to rest on the top of the head. Scale is a mechanical or electronic device used to measure the weight or mass of an object and human. Body Mass Index (BMI) is a calculated ratio of a person's height to weight which provides general information about a person's body composition [6, 7, 8]. Pietrobelli et al. [9] defined body mass index (BMI) as a measure of weight adjusted for height, calculated as weight in kilograms divided by the square of height in meters. The body mass index was considered an indicator of body fatness and also a surrogate measure of body fat because it measures excess weight rather than excess fat. BMI relies solely on height and weight as well with access to the proper equipment routinely measured and calculated with reasonable accuracy [10,11, 12]. Body fatness has been an important psychosocial issue among humans for millennia [13]. Body weight is influenced by the interaction of multiple factors. Body Mass Index is used to estimate healthy weight of average people. People with a BMI of 25 to 29.9 are considered overweight, and people with a BMI of 30 or above are considered obese [14]. Research had shown that individuals with a higher BMI are more likely to experience obesity-related health problems [15]. BMI categories are used worldwide for all adults 20 years and older. Some researchers established that BMI should serve as the initial screening of overweight and obesity for adults including children and adolescents [16-19]. BMI is a reasonable indicator of body fat for both adults and children [20-23]. BMI does not measure body fat directly, it should not be used as a diagnostic tool $[24,25]$. A health care provider should integrate other factors into a health assessment, including evaluations of diet, physical activity, family history, and other appropriate health screenings. 


\section{International Journal of Innovative Research in Electrical, Electronics, Instrumentation and Control Engineering}

Vol. 8, Issue 7, July 2020

It was indicated that BMI should be used as a measure to track weight status in populations and as a screening tool to identify potential weight problems in individuals [26, 27]. Measured height and weight are needed because self-reported data is not sufficiently reliable to follow population level trends or to make comparisons between populations [28]. The BMI as given in equation 1 according to [7]. Body Mass Index for Adults graphical data as shown in Fig. 1.

Boby Mass Index $(\mathrm{BMI})=\frac{\text { Weight }}{\text { Height }^{2}}$

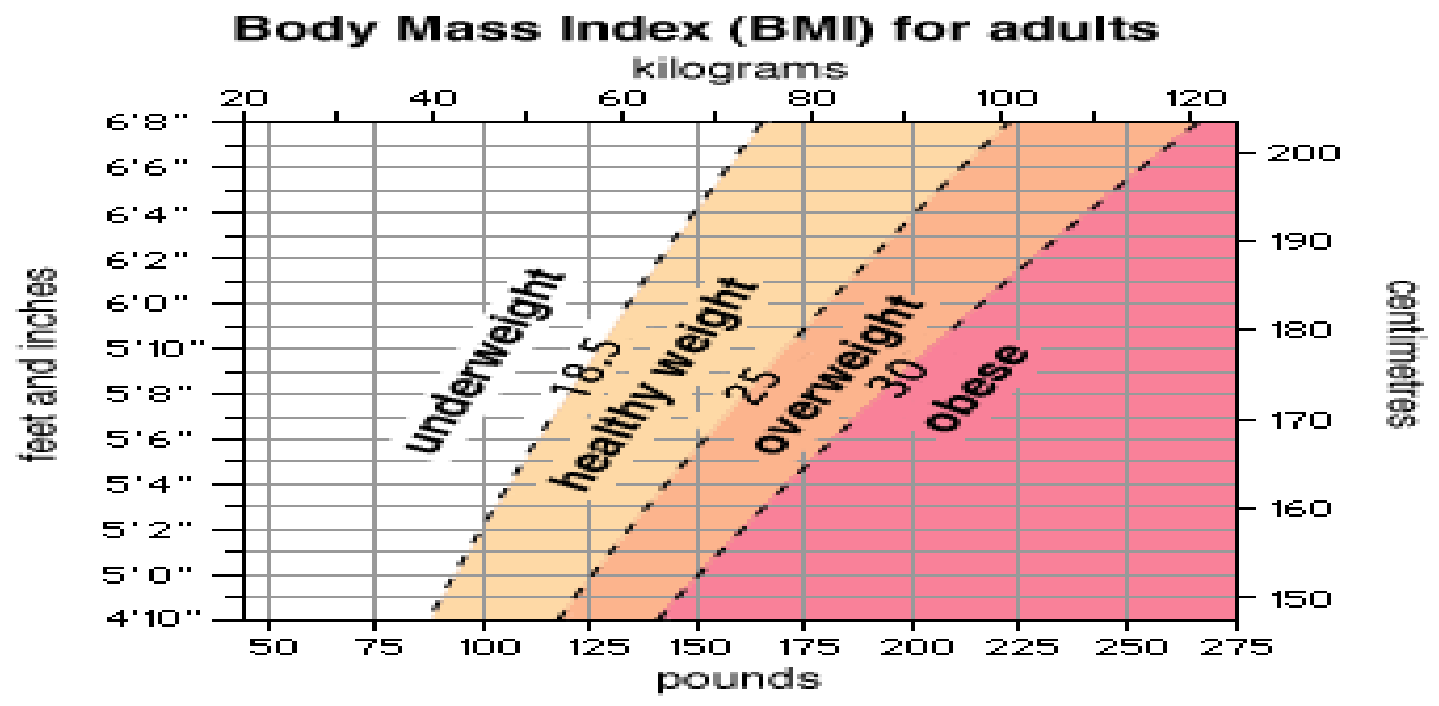

Fig. 1: Body Mass Index for Adults [29].

Foster [30] quoted from United states Centres for Disease Control and Prevention that studies showed that individuals who are overweight or obese run a greater risk of developing diabetes mellitus, hypertension, coronary heart disease, stroke, arthritis, and some forms of cancer. World Health Organization [31] stated that about 1.6 billion adults worldwide were overweight and 400 million were obese which was considered as global obesity epidemic. This research focused on the need to consider a parametric design of height and weight measuring system with the enlightenment of basic design principle. The convectional height and weight measurement equipment as shown in Fig. 2.

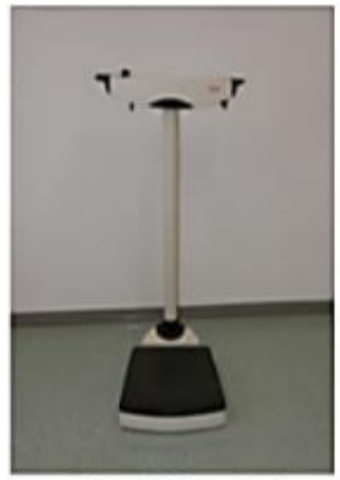

Balanced Beam Scale

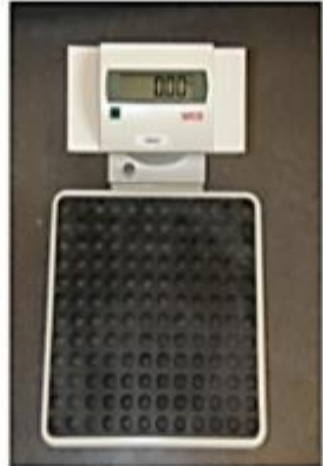

Electronic Scale

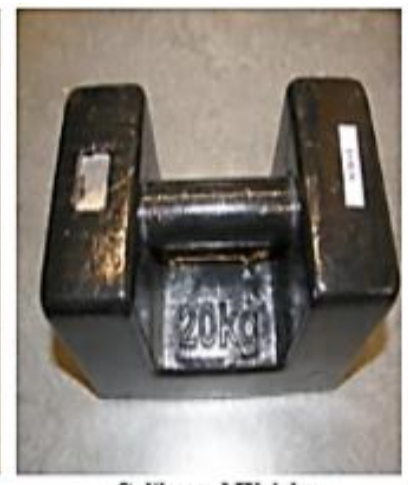

Calibrated Weights

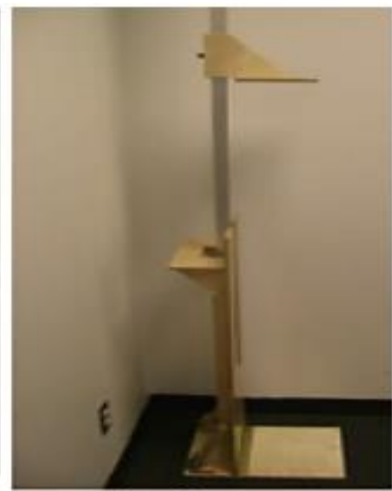

Stadiometer

Fig. 2: Weighing Balance and Stadiometer [28].

Most of the measurement systems contain three main functional elements such as primary sensing element, variable conversion element and data presentation element. Variable conversion element consist of variable manipulation element, data transmission element and data storage with playback element. Sensing element is the element in a measurement system that takes information about the condition being measured and transforms it into a more suitable form. Transducer is defined as a device which converts a physical quantity into an electrical quantity. Sensor is act as primary element of transducer [32-39].

Mediatoget [40] stated that the primary sensing element of a measurement system is detecting quantity to be measured (measurand) as a detector through the primary sensor which gives the output in a different analogous form. This output is then converted into an electrical signal by a transducer which converts energy from one form to another suitable form. The schematic diagram of a functional elements of an instrument as shown in Fig. 3. 


\section{International Journal of Innovative Research in Electrical, Electronics, Instrumentation and Control Engineering}

Vol. 8, Issue 7, July 2020
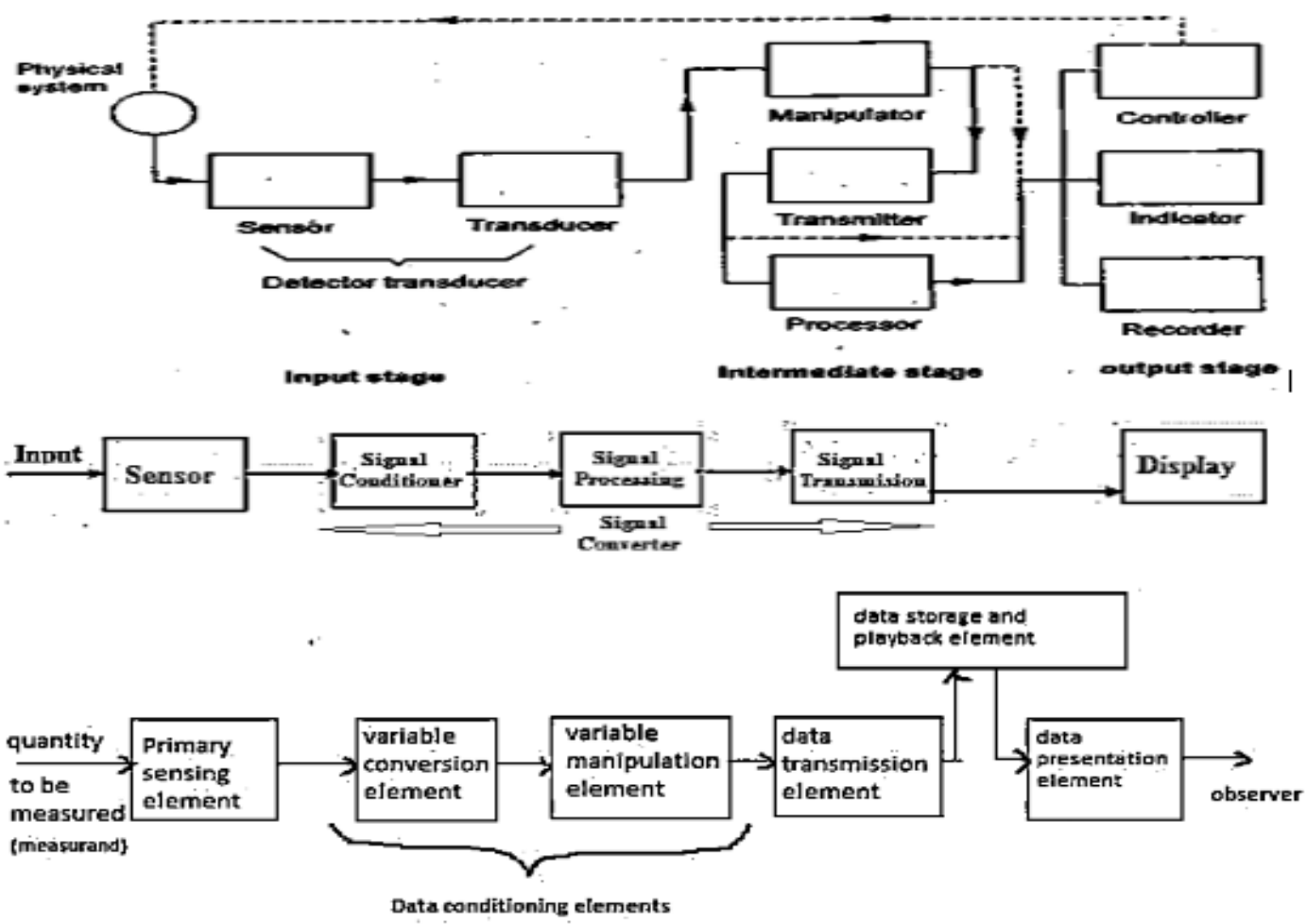

Fig. 3: Functional Elements of an Instrument [35].

Sanoner [41] studied on distance measuring device for acoustically measuring distance. The researcher used the device to determine the distance of an object through the transmitting and receiving of an acoustic signal. The velocity of acoustic signal and distance travel from transmitting the acoustic signal were compared with output generated.

Alexander et al. [5] worked on ultrasonic sensor based portable height measuring device. The microcontroller was used to send a trigger signal to the ultrasonic sensors in order to send bursts of ultrasound that reflect off the floor and return to the receiver. The time interval between the trigger and echo signal is the travel time of the ultrasound wave from sensors to the floor and back. The microprocessor then measured the time interval and used the speed of ultrasound to compute the round-trip distance.

Chen [42] performed experiment on portable human height measuring device. The device was consists of an ultrasonic distance sensor, a controller and several output units. It was used to convert the person's height to the proper measuring unit and communicated to the person via output units.

\section{METHODOLOGY}

\section{A. Materials and Methods}

The selection of a proper material and their properties is of great importance in designing of any expected functioning machine. The machine components should be made of such a material which has properties suitable for the conditions of operation. The best material is one which serves the desired objective of the machine to be designed and modelled. The major design consideration are strength, functionality, safety, reliability, utility, shape, ergonomics and aesthetics, analysis and control. The design consists of a step-by-step approach procedures from given specifications about the functional requirements of a product to the complete description in the form of drawings of the final product. An ergonomically designed system provides optimum performance. The aesthetic and ergonomics are very important features which gives grace and lustre to product of any design [1, 43, 44, 45].

\section{B. Materials}

The materials involved for the parametric design of height and weight measuring system under study are Load Cells with Strain Gauge, Sonar with Ultrasonic Sensors, Liquid Crystal Displays (LCD), Medium Density Fibreboard (MDF), Rubber Mounting, Microcontroller Arduino Board, Battery and Accessories.

\section{(1) Load Cell}

A load cell is a transducer used to create an electrical signal whose magnitude is directly proportional to the force being measured. Basically, it measures strain and then converts force into electrical energy [46]. The weight scale amplifier 


\section{International Journal of Innovative Research in Electrical, Electronics, Instrumentation and Control Engineering}

Vol. 8, Issue 7, July 2020

(HX711) is an auxiliary to the weight sensor for amplifying the signals from load cells and reporting it to microcontroller which allows to read easily when measured during the operation. The feature in Fig. 4 depict the load cell with the auxiliary.
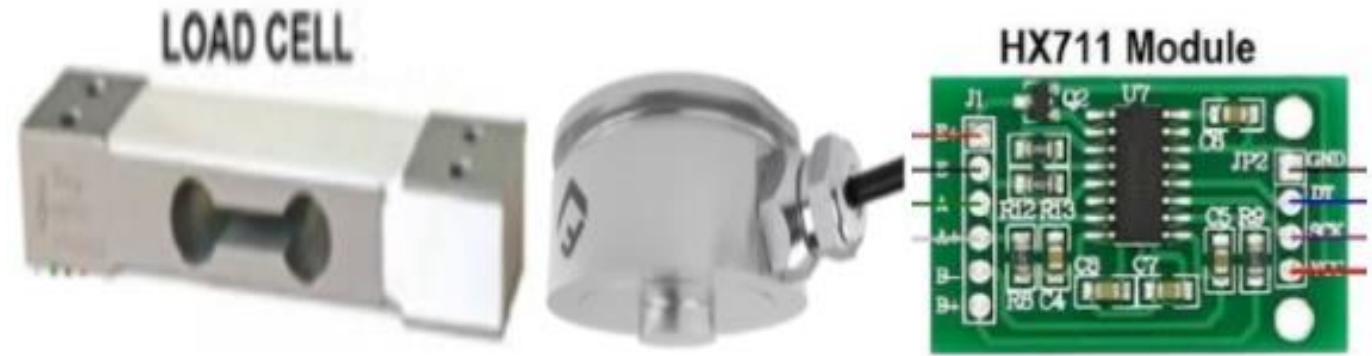

Fig. 4: Load Cell with Weight Scale Amplifier Module [46, 47].

(2) Microcontroller

Microcontroller is a complete computer on a chip, containing all of the elements of the basic microprocessor along with other specialized functions [48]. This serves as interface between the software and hardware component of the system as shown in Fig. 5.

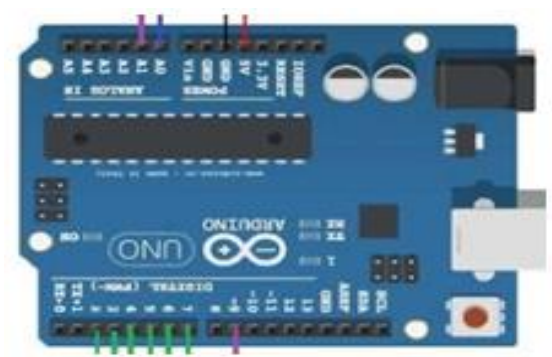

Fig. 5: Microcontroller [46]

\section{(3) Ultrasonic Sensor}

An ultrasonic sensor is an electronic device that measures the distance of a target object by emitting ultrasonic sound waves, and converts the reflected sound into an electrical signal. The output current or the output voltage is proportional to the level or distance of the media surface. Ultrasonic sensors have two main components: the transmitter, which emits the sound and the receiver, which encounters the sound after it has travelled to and from the target [49, 50]. The ultrasonic distance measuring sensor as shown in Fig. 6.

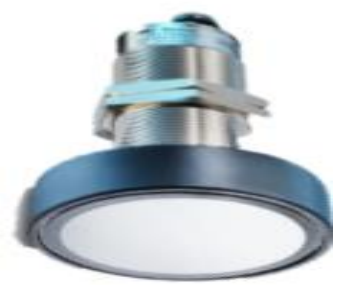

Fig. 6: Ultrasonic Sensor [49].

(4) Liquid Crystal Display (LCD)

Liquid crystal display is an electronic display device that operates by applying a varying electric voltage to a layer of liquid crystal, thereby inducing changes in its optical properties [51]. Fig. 7 depicts the feature of Liquid crystal display.

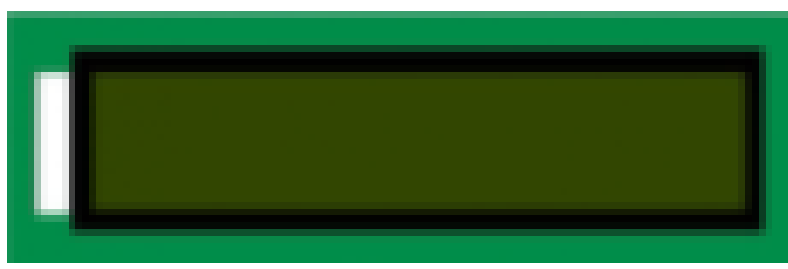

Fig. 7: Liquid Crystal Display [46]. 


\section{International Journal of Innovative Research in Electrical, Electronics, Instrumentation and Control Engineering}

Vol. 8, Issue 7, July 2020

(5) Battery

Battery is an electric cell device that converts chemical energy into electricity. The battery would be the power source for the weight and height measuring system as shown in Fig. 8. The rechargeable battery of 6 volts would be needed to supply direct current to the system and charging panel will be incorporated in the power system.

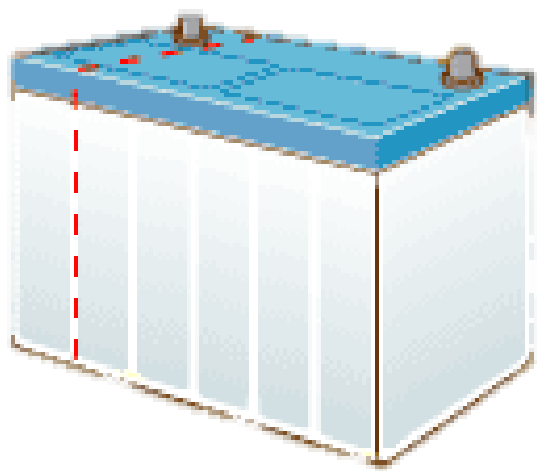

Fig. 8: Battery [52].

(6) Medium Density Fibreboard

Medium Density Fibreboard (MDF) is less dense than hardboard and it possesses excellent surface qualities, strong, durable and the ability to resist applied forces that might tend to change its shape and size due to its mechanical properties as shown in Fig. 9 [53].

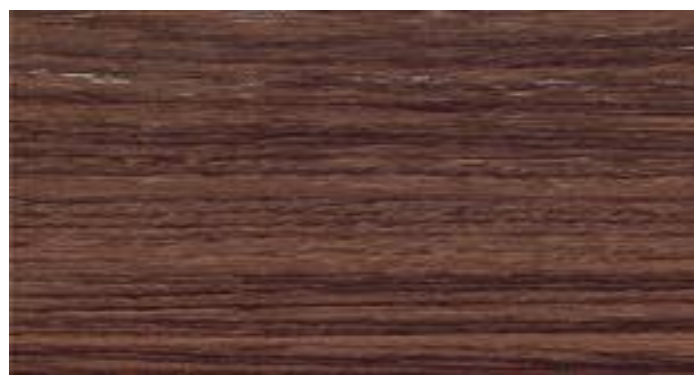

Fig. 9: Medium Density Fibreboard [54].

\section{(7) Rubber Mountings}

Rubber is a natural or synthetic substance characterized by elasticity, water repellence, electrical and corrosion resistance. Its elasticity, resilience and toughness makes it suitable for various kinds of shock absorbers and for specialized machinery mountings designed to reduce vibration as shown in Fig. 10 [55].

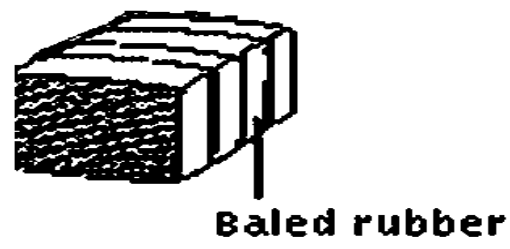

Fig. 10: Rubber [55].

(8) Accessories

Accessories are peripheral or add-on to the system that provides functions not available on the major components of the equipment such as Light emitting diode (LED), Zener diode, Resistors, Capacitor, Switch, Variable resistor, Integrated circuit (IC) socket, Oscillator, Power Circuit Board (PCB), Adapter, Regulator, Pin socket, Jack plug, Wires and Software. The symbols of the accessories as shown in Fig. 11. 


\section{International Journal of Innovative Research in Electrical, Electronics, Instrumentation and Control Engineering}

Vol. 8, Issue 7, July 2020
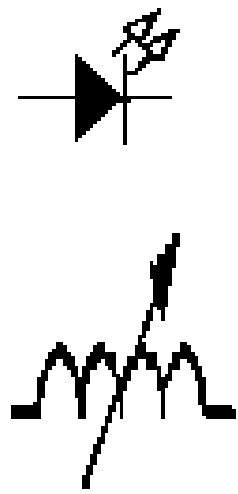

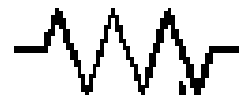

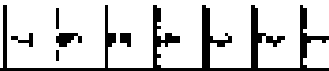

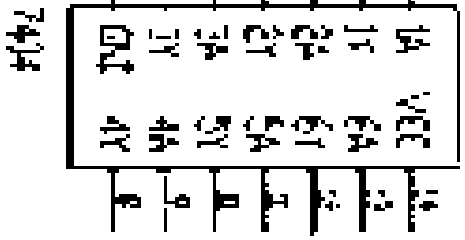

Fig. 11: Symbols of the Accessories [56].

\section{Methods}

The PTC Creo Parametric 3.0 drawing modelling software was used to draw the isometric and orthographic view of the height and weight measuring system. The 3D model of the system was created with $2 \mathrm{D}$ view to reveal the details of the modelled drawing. The design analyses of the various measuring devices were emphatically carried out in details.

D. Design Analysis of the Measuring System

The design analysis involves the quantitative of so many components that comprises the system to determine how functional, efficient and safe the designed system would be.

\section{(1) Compression Load Cells}

Electronic compression load cell was adopted, an electro-mechanical weight sensor which is used to measure force or weight. It has a simple yet effective design which relies upon the well-known transference between an applied force, material deformation and the flow of electricity. They are incredibly versatile devices that offer accurate and robust performance across a diverse range of applications as shown in Fig. 12. The gravitational force on the body being measured when is applied to an elastic element produces a measurable deflection $[47,57]$.
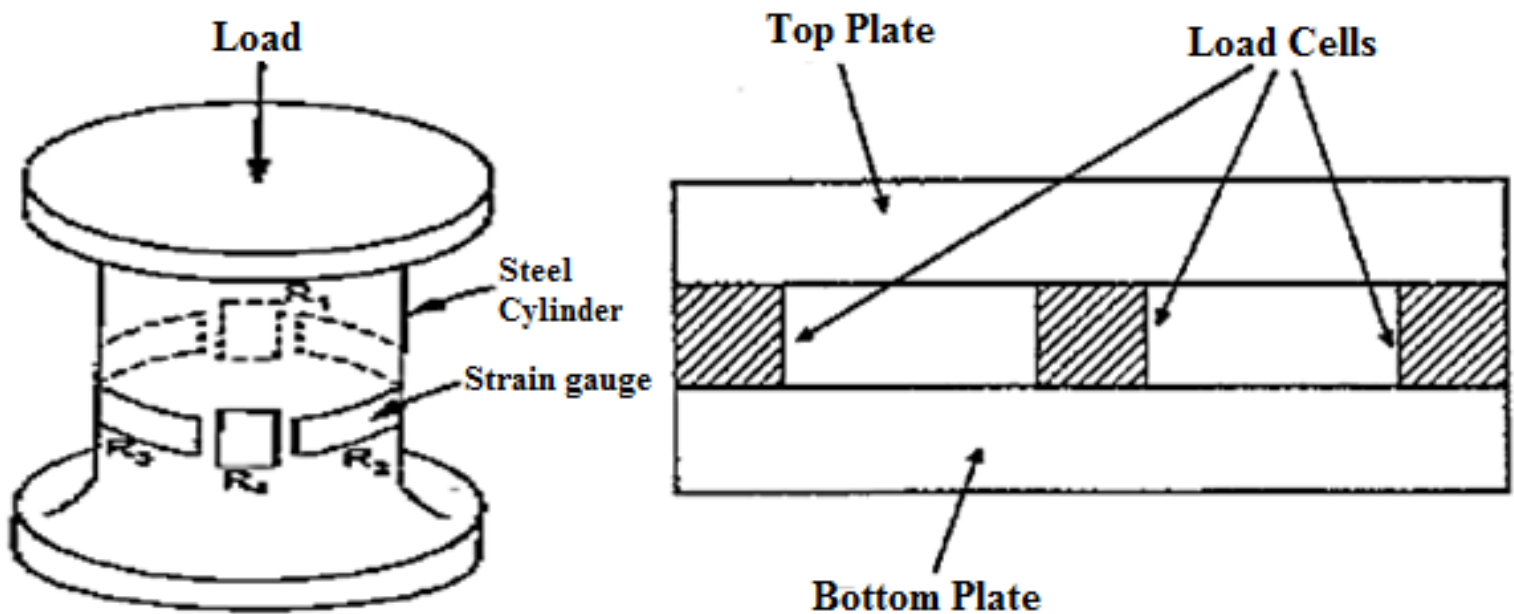

Fig. 12: Application of Load Cells [57]

Load cell as a sensing element has an input of a change in forces and an output of a change in length (elastic deformation). This deformation is then sensed by means of another sensor known as strain gauge, the resistors that changes its resistance when bent. The change in length is a measure of the change in weight [58].

Change in Forces (Input) $\rightarrow$ Change in Length (Output) $\rightarrow$ Change in Strain of Strain gauges

Electrical Strain is directly to proportional to the Mechanical Strain as given in equation 2 to 8 according to Webster [59].

Mechanical Strain $=\frac{\text { Change in Lenth }}{\text { Original Length }}$

Electrical Strain $=\frac{\text { Change in Resistance }}{\text { Original Resistance }}$ 


\section{International Journal of Innovative Research in Electrical, Electronics, Instrumentation and Control Engineering}

Vol. 8, Issue 7, July 2020

The change in resistance of a strain gauge of resistance $\mathrm{R}$ when subject to a strain $\varepsilon$ is given by equation 4 .

Change in resistance, $\Delta \mathrm{R}=\mathrm{RK \varepsilon}$

$$
\frac{\Delta \mathrm{R}}{\mathrm{R}} \propto \frac{\Delta \mathrm{L}}{\mathrm{L}} \rightarrow \frac{\Delta \mathrm{R}}{\mathrm{R}}=\mathrm{K} \varepsilon
$$

Gauge factor, $K=\frac{\text { Electrical Strain }}{\text { Mechanical Strain }}=\frac{\text { Fractional Change in Resistance }}{\text { Fractional Change in Length }}=\frac{\frac{\Delta R}{R}}{\frac{\Delta L}{L}}$

Thus, the response of the strain gauges is obtained as given in equation 7 .

$$
\frac{\Delta \mathrm{R}_{1}}{\mathrm{R}_{1}}=-\frac{\Delta \mathrm{R}_{2}}{\mathrm{R}_{2}}=\frac{\Delta \mathrm{R}_{3}}{\mathrm{R}_{3}}=-\frac{\Delta \mathrm{R}_{4}}{\mathrm{R}_{4}}=\frac{6 \mathrm{~S}_{\mathrm{gPx}}}{\mathrm{Ebh}^{2}}
$$

The output voltage $\mathrm{E}_{\mathrm{O}}$ from the Wheatstone bridge, resulting from application of the load $\mathrm{P}$, is obtained as given in equation 6 . If the four strain gauges of the load cells are assumed to be identical, equation 8 is obtained.

$\mathrm{E}_{O}=\frac{6 \mathrm{~S}_{\mathrm{gPxE}}}{\mathrm{Ebh}^{2}}$

The range and sensitivity of a beam-type load cell depends on the shape of the cross-section of the beam, the location of the point of application of the load.

(2) Vibrating Wire Sensor

This instrument consists of a wire that is kept vibrating at its resonant frequency by a variable-frequency oscillator as shown in Fig. 13. The resonant frequency of a wire under tension is given by equation 9 . The measurement of the output frequency of the oscillator allows the force applied to the wire to be calculated, this assist the load cell [57].

$\mathrm{f}=\frac{1}{2 \mathrm{~L}} \sqrt{\left(\frac{\mathrm{M}}{\mathrm{T}}\right)}$

where: $\mathrm{M}$ is the mass per unit length of the wire, $\mathrm{L}$ is the length of the wire and $\mathrm{T}$ is the tension due to the applied force.

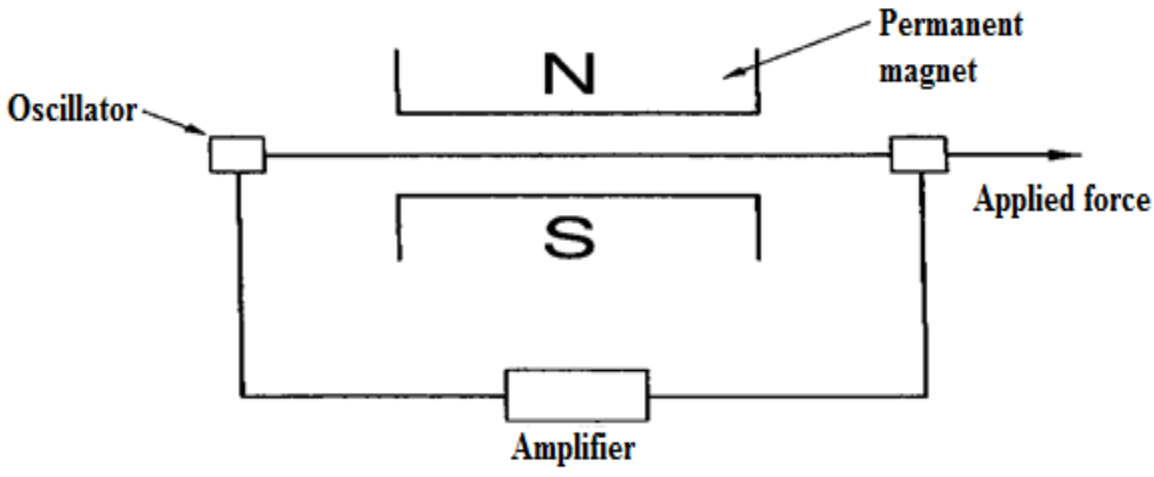

Fig. 13: Vibrating Wire Sensor Incorporated with the Load Cell [57].

(3) Sonar with Distance Ultrasonic Sensor

Ultrasonic waves have long been used for detection and communication devices called sonar. Two Ultrasonic device can be used for distance measurement. Ultrasonic waves can be used to measure distances from 1 to about $50 \mathrm{~m}$. An ultrasonic transducer is a device used to convert some other type of energy into an ultrasonic vibration. The time for a pulse of energy to travel to an object and be reflected back to a receiver is measured, from which the distance can be calculated, the speed of ultrasonic waves is $340 \mathrm{~m} / \mathrm{s}$ [60-63]. The formular to determine the distance through the distance ultrasonic sensors as given in equation 10 to 13 .

$\mathrm{v}=\mathrm{f} \lambda$

$\mathrm{f}=\frac{1}{\mathrm{~T}}$

$\mathrm{v}=\frac{\lambda}{\mathrm{T}}$

$\lambda=\mathrm{VT}$

Ultrasonic waves from the transmitter are reflected by the surface of the object to the receiver; the time for the waves to reach the receiver is measured. The time delay gives the distance from the transmitter and receiver to the surface of the object, from which the distance can be calculated knowing the velocity of ultrasonic waves. The feature of the operation of ultrasonic distance sensor as shown in Fig. 14. 


\section{International Journal of Innovative Research in Electrical, Electronics, Instrumentation and Control Engineering}

Vol. 8, Issue 7, July 2020

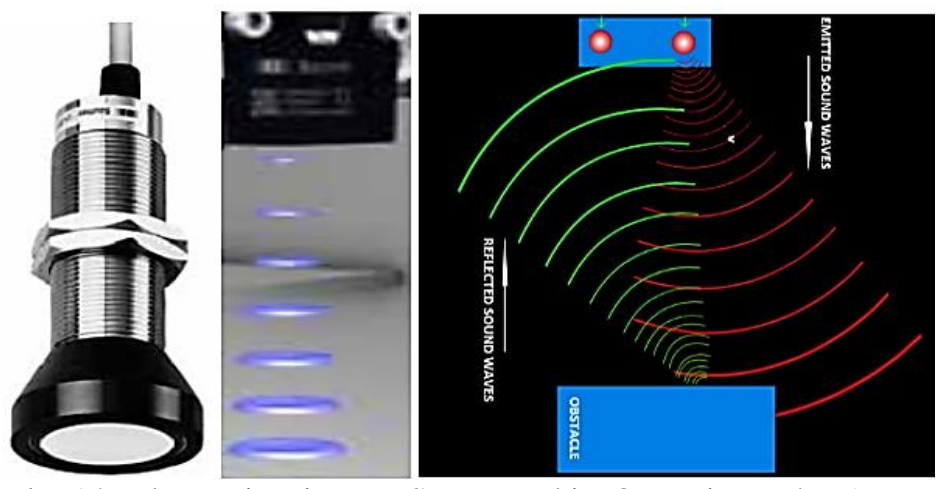

Fig. 14: Ultrasonic Distance Sensor and its Operation [64, 65, 66].

(4) Medium Density Fibreboard (MDF)

Medium Density Fibreboard has many advantages over natural wood such as dimensional stability uniformity of strength, resistance to splitting, panel form and decorative value with thermal and sound insulating properties as shown in Fig. 9 above. It is very adaptable to various applications. It possesses excellent surface qualities and is strong and durable. The range of thicknesses of MDF is from $6-40 \mathrm{~mm}$ with density range of $517-834 \mathrm{~kg} / \mathrm{m}^{3}$ of which the average density is $680 \mathrm{~kg} / \mathrm{m}^{3}$. The speed of sound in wood longitudinally is about $3500-5000 \mathrm{~m} / \mathrm{s}$.

Table I: Mechanical Properties of Medium Density Fibreboard (MDF)

\begin{tabular}{ll}
\hline \multicolumn{1}{c}{ Properties of Medium Density Fibreboard } & \multicolumn{1}{c}{ Parameters Value } \\
\hline Density & $680 \mathrm{~kg} / \mathrm{m}^{3}$ (Average) \\
Modulus of Elasticity & $105 \mathrm{~N} / \mathrm{mm}^{2}$ \\
Modulus of Rigidity & $12280 \mathrm{~N} / \mathrm{mm}^{2}$ \\
Tension Stress (Transverse) & $5.5 \mathrm{~N} / \mathrm{mm}^{2}$ \\
Compression Stress (Transverse) & $9.1 \mathrm{~N} / \mathrm{mm}^{2}$ \\
Toughness & $36.7 \mathrm{Nm}$ \\
Hardness & $6.0 \mathrm{kN}$ \\
\hline
\end{tabular}

Source: $[67,68]$.

The size of the MDF to be used on load cell as platform is: Length $=0.5 \mathrm{~m}$, Width $=0.4$ and Thickness $=0.04 \mathrm{~m}$ The equation 14 to 19 used to determine the integrity of the weight measuring system platform according to [43]. Weight, $\mathrm{W}=$ Density, $\rho \times$ Volume, $\mathrm{V} \times$ Acceleration due to Gravity, $\mathrm{g}=\rho \mathrm{Vg}$ Assumed $15 \%$ Factor of safety

The weight is $\mathbf{6 0} \mathbf{~ N}$

The maximum weight of a man is $1200 \mathrm{~N}(120 \mathrm{~kg})$, the average weight of man as male and female are $888 \mathrm{~N}(88.8 \mathrm{~kg})$ and $764 \mathrm{~N}(76.4 \mathrm{~kg})$ respectively [69].

The total weight that will act on the MDF is $1260 \mathbf{~ N}$

The shear force is $630 \mathrm{~N}$

The maximum bending moment of the MDF under load as given in equation 15

Maximum Bending Moment, $\mathrm{M}_{\max }=$ Reaction force, $\mathrm{R} \times$ Perpendicular distance

The maximum bending moment is $\mathbf{1 2 6} \mathbf{~ N m}$

The compressive stress induced due to load to undergo during the operation as given in equation 16

Compressive Stress, $\sigma_{C}=\frac{\text { Maximum Load }}{\text { Cross Sectinal Area }}=\frac{\mathrm{P}_{\max }}{\mathrm{A}}$

Compressive Stress, $\sigma_{C}$ is $\mathbf{6} \mathbf{~ k N / \mathbf { m } ^ { 2 }}$

The stress induced due to bending moment as given in equation 17 and 18

Stress, $\sigma$ is $605 \mathrm{~N} / \mathrm{m}^{2}$

$$
\begin{aligned}
& \frac{\mathrm{M}}{\mathrm{I}}=\frac{\sigma}{\mathrm{y}} \\
& \mathrm{I}=\frac{\mathrm{bl}^{3}}{12}
\end{aligned}
$$

Deflection of the MDF under concentrated load as given in equation 19

Deflection, $\delta$ is $\mathbf{0 . 0 0 0 0 0 4} \mathbf{~ m}$

$$
\text { Deflection, } \delta=\frac{\mathrm{Wl}^{3}}{48 \mathrm{EI}}
$$


International Journal of Innovative Research in Electrical, Electronics, Instrumentation and Control Engineering

Vol. 8, Issue 7, July 2020

E. Modelling Parts and Assembling

The 3D models view of the parts in the PTC Creo Parametric software. This 3D model give a simplified assembly view of the part as shown in Fig. 15.
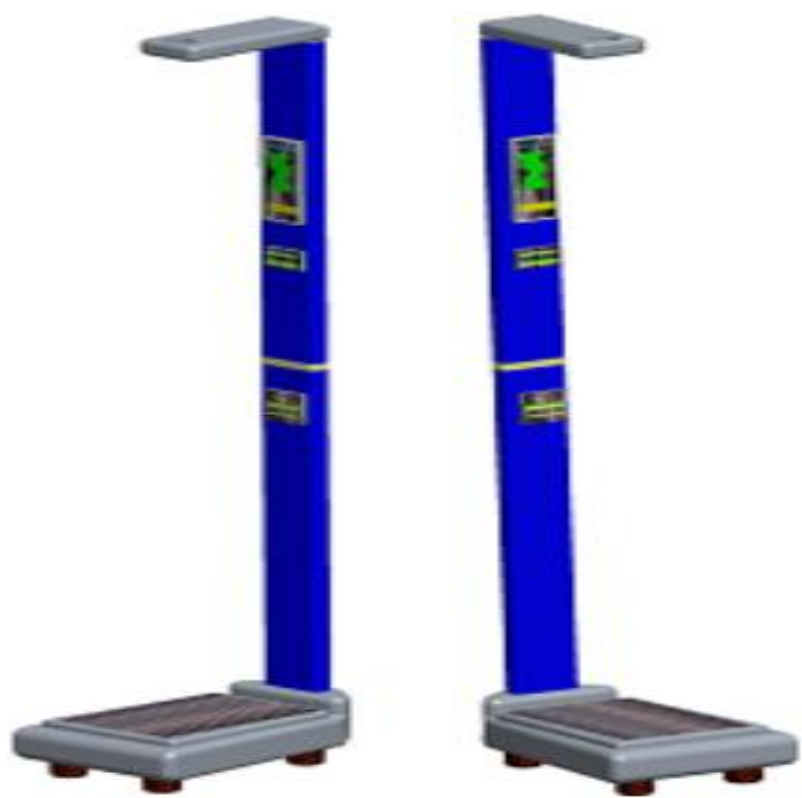

Fig. 15: 3D Modelling of the Weight and Height Measuring System with BMI Computation

\section{F. Flow Chart of the Program of the Body Mass Index Computation}

This algorithm describes the computation of the body mass index from the weight and height measured parameters from the system as shown in Fig. 16.

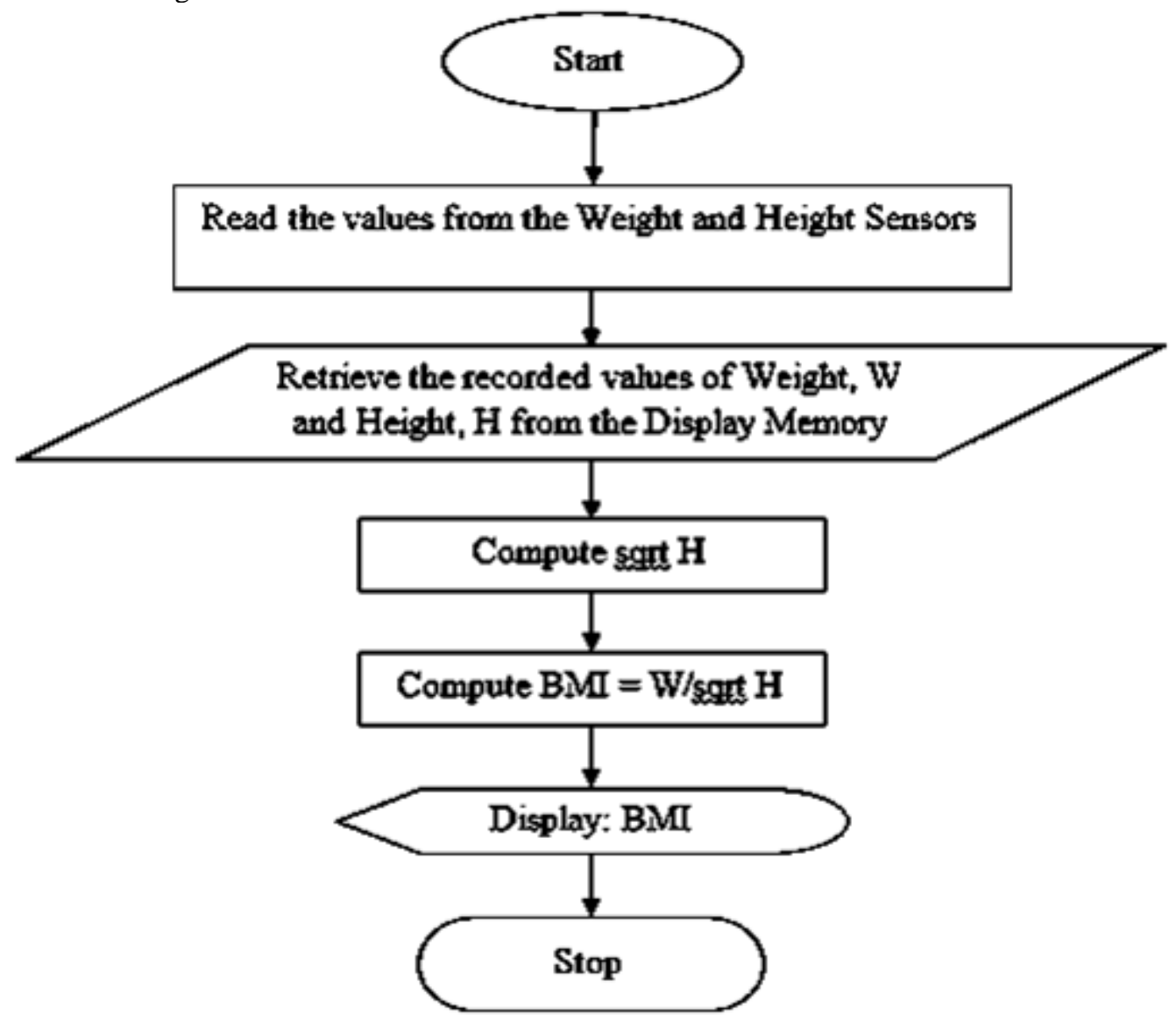

Fig. 16: Algorithm for the Body Mass Index Computation 


\section{IJIREEICE \\ International Journal of Innovative Research in Electrical, Electronics, Instrumentation and Control Engineering}

Vol. 8, Issue 7, July 2020

\section{RESULTS AND DISCUSSION}

The arrangement of the component for the weight measuring system which comprise load cell (weight sensor), weight amplifier (booster) module, microcontroller (arduino) board, liquid crystal display (LCD) as shown in Fig. 17

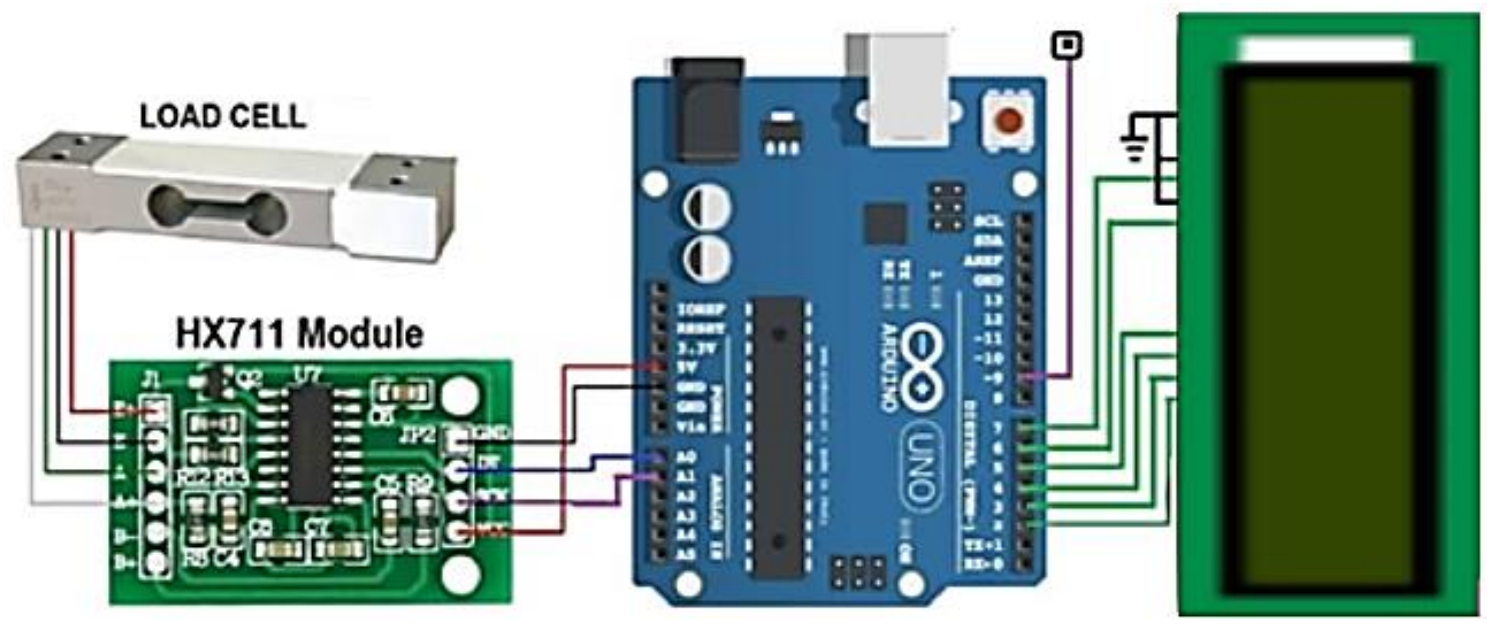

Fig. 17: Component for the Weight Measuring System

The height of the system for the measuring of the height is about $2.1 \mathrm{~m}$ (7 Feet), the area of the stand platform for the measuring of the weight is about $0.2 \mathrm{~m}^{2}$. The weight sensor for the design could measure from 1-200 kg with accuracy of about $\pm 0.1 \mathrm{~kg}$. The height measuring sensor could measure through a scanning range of $0.4 \mathrm{~m}$ to $2.5 \mathrm{~m}$ with accuracy of about $\pm 1 \mathrm{~mm}$, resolution of $\pm 0.3 \mathrm{~mm}$ and response time of less than 160 microsecond (ms). The sonic frequency of about $120 \mathrm{kHz}$ and output current range from 4 to 20 milliampere (mA). The circuitry of the anthropometry medical measuring system as shown in Fig. 18.

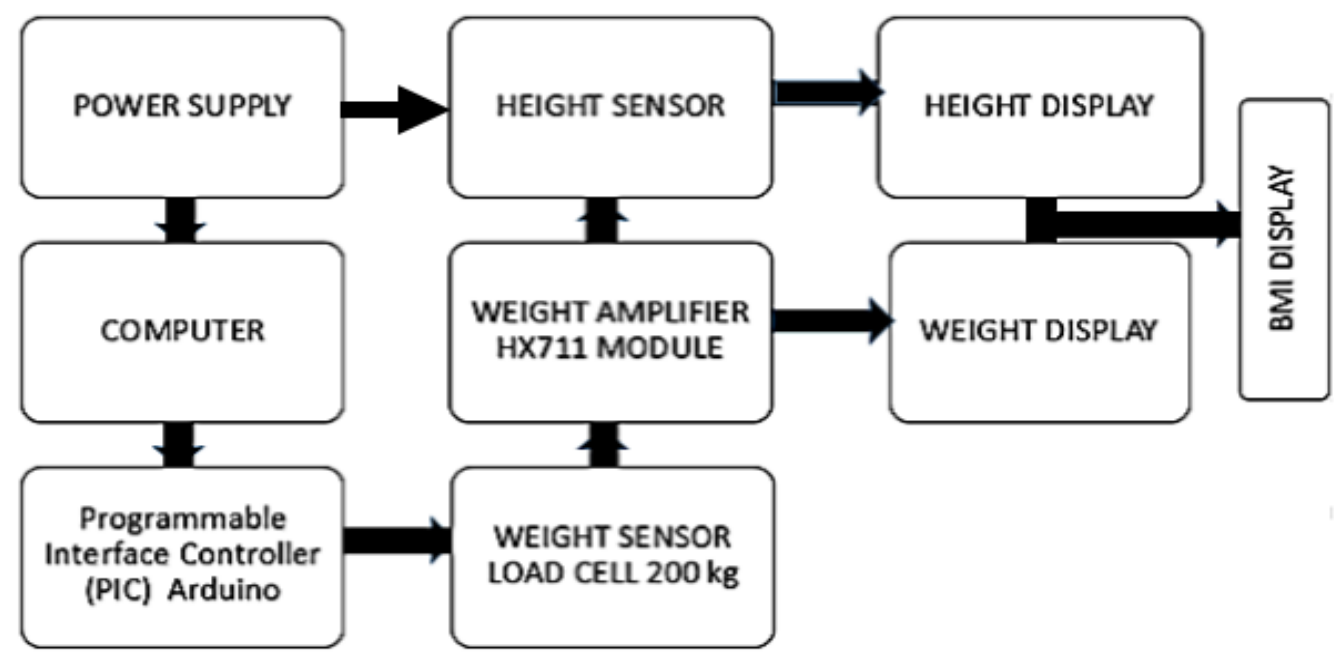

Fig. 18: Circuitry of the Anthropometry Measuring System

The manikin of the anthropometry measuring system modelled by the PTC Creo Parametric 3.0 drawing modelling software to show how the person to be measured would stand for the measurement as shown in Fig. 19. 


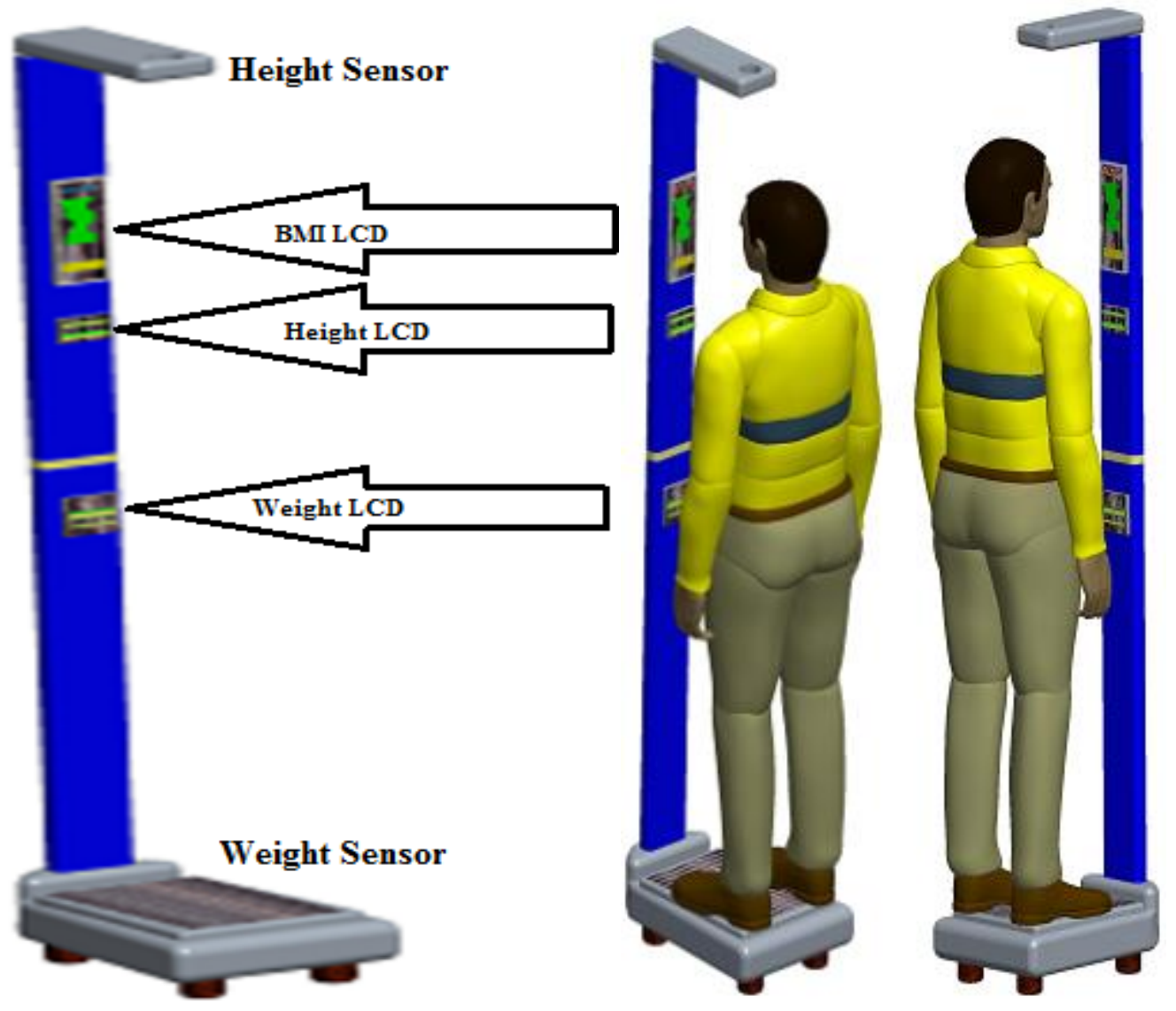

Fig. 19: The Manikin of Anthropometry Medical Measuring System

\section{CONCLUSION}

The design of the weight and height measuring system for medical anthropometry has been completed and the aim was immensely achieved. The results from the design analysis revealed that the system weight sensor platform has shear force of $630 \mathrm{~N}$, maximum bending moment of $126 \mathrm{Nm}$. The compressive stress that could be induced during measurement of maximum human weight is $6 \mathrm{kN} / \mathrm{m}^{2}$ and stress that could be induced due to maximum bending moment is amount to $605 \mathrm{~N} / \mathrm{m}^{2}$. The amount by which weight sensor platform could deflect when subjected to bending moment is $0.000004 \mathrm{~m}$. These values indicating that the design is safe for operation which is far lesser than the property parameters of the materials used for the weight sensor platform. The range of measurement of weight sensor is $1 \mathrm{~kg}$ to $200 \mathrm{~kg}$ with accuracy of about $\pm 0.1 \mathrm{~kg}$ and that of ultrasonic distance sensor is $0.4 \mathrm{~m}$ to $2.5 \mathrm{~m}$ with accuracy of about $\pm 1 \mathrm{~mm}$, resolution of $\pm 0.3 \mathrm{~mm}$. The time for the ultrasonic sensor to response to measure the height is less than 160 microsecond (ms) during on and off respectively.

\section{REFERENCES}

[1]. Bhandari, V.B.(2010). Design of Machine Elements, Third Edition, Tata McGraw Hill Education Private Limited, West Patel Nagar, New Delhi110008 , India. pp. 1-6. ISBN-13: 978-0-07-068179-8, ISBN-10: 0-07-068179-1.

[2]. Aderoba, A. A. (2011). Paradox of Human Anatomy in Engineering Design, Workshop on Advanced Manufacturing Technology, Engineering Materials Development Institute (EMDI), Akure, Nigeria.

[3]. Udosen, U. J. (1998). Work Systems Design and Measurements, Essec Classic Nigerian Company, Uyo, Nigeria.

[4]. Encyclopeadia Britannica (2013). Anthropometry. Encyclopeadia Britannica Article, Encyclopeadia Britannica Ultimate Reference Suite, USA.

[5]. Alexander N., Michael H., Anthony M., Jiang W. and Ying S. (2017). An Ultrasonic Sensor Based Portable Height Measuring Device. Conference Paper. 43rd Annual Northeast Bioengineering Conference, NJIT, Newark, NJ. https://www.researchgate.net/publication/326905128

[6]. Weight and Height Instruments Preliminary (2020). Height and Weight Measurement Training. https://www.udallas.edu/care

[7]. Arkansas Center for Health Improvement, ACHI (2018). BMI Screening Program Height and Weight Measurement Training Manual, 1401 West Capitol Avenue, Suite 300, Victory Building, Little Rock, Arkansas 72201, www.achi.net

[8]. Blackburn, H. and Jacobs, D. (2014). "Commentary: Origins and Evolution of Body Mass Index (BMI): Continuing Saga", International Journal of Epidemiology. 43 (3): 665-669. doi:10.1093/ije/dyu061. PMID 24691955.

[9]. Pietrobelli, A., Faith, M., Allison, D., Gallagher, D., Chiumello, G., \& Heymsfield, S. (1998). Body Mass Index as a Measure of Adiposity Among Children and Adolescents: A Validation Study, Journal of Pediatrics, 132, 204-210.

[10]. Daniels, S. (2009). The use of BMI in the clinical setting. Pediatrics, 124(Supplement1), S35-S41. 


\title{
International Journal of Innovative Research in Electrical, Electronics, Instrumentation and Control Engineering
}

\author{
Vol. 8, Issue 7, July 2020
}

[11]. Daniels, S., Khoury, P. and Morrison, J. (1997). The Utility of Body Mass Index as a Measure of Body Fatness in Children and Adolescents: Differences by Race and Gender. Pediatrics, 99, 804-807.

[12]. Lesser, G. (2007). Issues in Body Fat Measurement Archives of Internal Medicine, 169 (6), 636.

[13]. Nuttall, F. Q. (2015). Body Mass Index Obesity, BMI, and Health: A Critical Review, Vol 50, Number 3. DOI: 10.1097/NT.0000000000000092

[14]. Encarta, (2009). "Body Mass Index". Microsoft Encarta Premium, Microsoft Corporation, Redmond, Washington D. C., USA.

[15]. National Obesity Observatory (2009). Body Mass Index as a Measure of Obesity. Association of Public Health Observatories, NHS, England.

[16]. Dietz, W., Story, M., \& Leviton, L. (2009). Introduction to Issues \& Implications of Screening, Surveillance and Reporting of Children's BMI. Pediatrics, 124 (Supplement1), S1-S2.

[17]. Barlow, S., \& Expert Committee (2007). Expert Committee Recommendations Regarding the Prevention, Assessment, Treatment of Child, Adolescent Overweight and Obesity: Summary Report. Pediatrics, 120, S164-S192.

[18]. Dietz, W., \& Bellizzi, M. (1999). Introduction: The Use of Body Mass Index to Assess Obesity in Children. American Journal of Clinical Nutrition, 70 (Supplement), 123S-125S

[19]. Horlick, M. (2001). Body Mass Index in Childhood Measuring a Moving Target. 86, 9, 4059-4060

[20]. Centres for Disease Control and Prevention, CDC (2009). Body Mass Index: Considerations for Practitioners. "Safer Healthier People". Department of Health and Human Services, USA.

[21]. Prentice, A., \& Jebb, S. (2001). Beyond body mass index. Obesity Reviews, 2, 141 -147.

[22]. Himes, J. (2009). Challenges of Accurately Measuring and Using BMI and Other Indicators of Obesity in Children. Pediatrics, 124(Supplement1), S3-S22.

[23]. Mei, Z., Grummer-Strawn, L., Pietrobelli, A., Goulding, A., Goran, M., \& Dietz, W. (2002). Validity of the Body Mass Index Compared with Other Body Composition Screening Indexes for the Assessment of Body Fatness in Chilidren and Adolescents, American Journal of Clinical Nutrition, 75, 978-985.

[24]. Freedman, D., Ogden, C., Berenson, G., \& Horlick, M. (2005). Body Mass Index and Body Fatness in Childhood. Current Opinion in Clinical Nutrition and Metabolic Care, 8, 618-623.

[25]. Garn, S., Leonard, W., \& Hawthorne, V. (1986). Three Limitations of the Body Mass Index. American Journal of Clinical Nutrition, 44, 996-997.

[26]. Gallagher, D., Visser, M., Sepulveda, D., Pierson, R., Harris, T., \& Heymsfield, S. (1996). How Useful is Body Mass Index for Comparison of Body Fatness across Age, Sex and Ethnic Groups? American Journal of Epidemiology, 143(3), 228-239.

[27]. Must, A., \& Anderson, S. (2006). Body Mass Index in Children and Adolescents: Considerations for Population-Based Applications. International Journal of Obesity, 30, 590-594.

[28]. Johanna, M. (2020). Measuring Height and Weight. Measuring the Health of Europeans, Second European Health Examination Survey, EHES Training Seminar

[29]. National Institutes of Health/National Heart, Lung and Blood Institute (2003). Body Mass Index for Adults, Encyclopeadia Britannica Article, Encyclopeadia Britannica Ultimate Reference Suite, Chicago, USA

[30]. Foster, G. D. (2009). "Obesity" Microsoft Encarta Premium, Microsoft Corporation, Redmond, Washington D. C., USA.

[31]. World Health Organization, WHO (2005). The Obesity Epidemic. Encyclopeadia Britannica Article, Encyclopeadia Britannica Ultimate Reference Suite, Chicago, USA.

[32]. Morris, A. S. (2003). Principles of Measurements and Instrumentation, Second Edition, Prentice Hall of India Private Limited, India.

[33]. Reissland, M. (2001). "Electrical Measurements", New Age International (P) Limited, Delhi, India.

[34]. Bouwens, A. J. (1997). "Digital Instrumentation", Tata McGraw Hill Education Private Limited, New York, USA.

[35]. Moorthy, D. V. S. (2007). 'Transducers and Instrumentation', Prentice Hall of India Private Limited, India.

[36]. Kalsi, H. S. (2004). "Electronic Instrumentation", Second Edition Tata McGraw Hill Education Private Limited, New York, USA.

[37]. Sawhney, A. K. (2004). A Course in Electrical, Electronic Measurements and Instrumentation, Dhanpat Rai \& Co., India.

[38]. Gupta, J. B. (2003). "A Course in Electronic and Electrical Measurements", S. K. Kataria \& Sons, Delhi, India

[39]. Doebelin, E. O. and Manik, D. N. (2007). Measurement Systems: Applications and Design, Special Indian Edition, Tata McGraw Hill Education Private Limited, New York, USA.

[40]. Mediatoget (2012). Generalized Measurement System. http://mediatoget.blogspot.in/2012/01/generalized-measurementsystem.html

[41]. Sanoner, H. (2008). Distance Measuring Device for Acoustically Measuring Distance. The Journal of the Acoustical Society of America, 123 (2), 583. doi:10.1121/1.2857655

[42]. Chen, P. P. Z. (2005). "Portable Human Height Measuring Device” United States Patent, Patent No.: USOO6847586B1

[43]. Khurmi, R. S. and Gupta, J. K. (2005). A Textbook of Machine Design' Fourteenth Edition Eurasia Publishing House Private Limited, Ram Nagar, New Delhi-110 055, India. pp. 16-52. http://www.simpopdf.com

[44]. Juvinall, R. C. and Marshek, K. M. (2012). Fundamentals of Machine Component Design. Fifth Edition, John Wiley \& Sons, Inc., 111 River Street, Hoboken, NJ07030-5774, New Jersey, USA. Pp. 1-14. ISBN-13 9781118012895. http://www.wiley.com/go/permissions.

[45]. Hedge, A. (2009). "Ergonomics." Microsoft Encarta Premium, Microsoft Corporation, Redmond, Washington D. C., USA.

[46]. Alam (2020). Weighhing Machine using Arduino Load Cell and HX711 Module. https://how2electronics.com

[47]. Flintec (2020). Weight Sensors Load Cells. Technology of a Load Cell. https://www.flintec.com

[48]. Bernstein, G. H. (2009). "Microprocessor." Microsoft Encarta Premium, Microsoft Corporation, Redmond, Washington D. C., USA

[49]. Baumer Electric AG (2020). Functionality and Technology of Level Sensors: Ultrasonic Level Measurement, Hummelstrasse 17, 8501 Frauenfeld, Switzerland. www.baumer.com

[50]. Jost, D.(2019). Fundamental: What is an Ultrasonic Sensor? FierceElectronics, Questex LLC, 3 Speen St, Suite 300, Framingham, MA 01701.

[51]. Dunmur, D. (2013). Liquid Crystal Display (LCD). Encyclopeadia Britannica Article, Encyclopeadia Britannica Ultimate Reference Suite, Chicago, USA.

[52]. Encyclopædia Britannica (2005). Lead-Acid Storage Battey. Encyclopeadia Britannica Incorporated, Encyclopeadia Britannica Ultimate Reference Suite, Chicago, USA.

[53]. Briggs, D. (2009). "Forest Industry." Microsoft Encarta Premium, Microsoft Corporation, Redmond, Washington D. C., USA.

[54]. USDA Forest Service (2013). Forest Products Laboratory. Encyclopeadia Britannica Article, Encyclopeadia Britannica Ultimate Reference Suite, Chicago, USA.

[55]. Lewin, S. Z. (2009). "Rubber." Microsoft Encarta Premium, Microsoft Corporation, Redmond, Washington D. C., USA.

[56]. Blastsoft (1996). Electronics Workbench, Version 5.12, Interactive Image Technologies Limited, Serial Number: RBS-1999-RBS

[57]. Morris, A. S. (2001). Measurement and Instrumentation Principles, Butterworth-Heinemann Linacre House, Jordan Hill, Oxford OX2 8DP 225 Wildwood Avenue, Woburn, MA 01801-204, New Delhi, India. 


\section{International Journal of Innovative Research in Electrical, Electronics, Instrumentation and Control Engineering}

Vol. 8, Issue 7, July 2020

[58]. Bicha, K and Prasuna, L. (2015). Digital Notes of Mechanical Measurements and Control Systems for Bachelor of Technology, Department of Mechanical Engineering, Malla Reddy College of Engineering \& Technology (Autonomous Institution - UGC, Govt. of India), Maisammaguda, Dhulapally (Post Via. Kompally), Secunderabad - 500100, Telangana State, India.

[59]. Webster, J. G. (1999). The Measurement, Instrumentation and Sensors Handbook CRCnetBASE 1999 CRC Press LLC, 2000 Corporate Blvd., N.W., Boca Raton, FL 33431.

[60]. Beyer, R. T. (2009). "Sonar" Microsoft Encarta Premium, Microsoft Corporation, Redmond, Washington D. C., USA.

[61]. Dunn, W. C. (2005). Fundamentals of Industrial Instrumentation and Process Control, McGraw-Hill Companies, Inc., USA.

[62]. Northrop, R. B. (2005). Introduction to Instrumentation and Measurements. CRC Press, Taylor \& Francis Group, 6000 Broken Sound Parkway NW, Suite 300, Boca Raton, FL 33487-2742

[62]. Njafi, K. and Mastrangelo, C. H. (1993). Solid-state Microsensors and Smart Structure, Ultrasonic Symposium, Baltimore, MD, 341-350.

[64]. Baumer Electric AG (2018). Ultrasonic Sensors: Ultrasonic Distance Measuring Sensors, UNAM 50I6121, Hummelstrasse 17, 8501 Frauenfeld, Switzerland. www.baumer.com

[65]. Baumer Electric AG (2019). Passion for Sensors: Reliable Level Measurement, UR 18, Hummelstrasse 17, 8501 Frauenfeld, Switzerland. www.baumer.com

[66]. Mouser Electronic (2020). Ultrasonic Sensor Diagram, Robo Galaxy. www.mouser.com

[67]. Dinwoodie, J. M. (1996).Timber: Structure, Properties, Conversion and Use, Seventh Edition Revised. H. E. Desch, USA.

[68]. Haygreen, J. G. and Bowyer, J. L. (1996). Forest Products and Wood Science: Wood Structure, Properties and Technology of Major Forest Products, Third Edition, USA

[69]. Reference Data (2014). Anthropometric Reference Data, United States Department of Health \& Human Services, USA.

\section{BIOGRAPHIES}

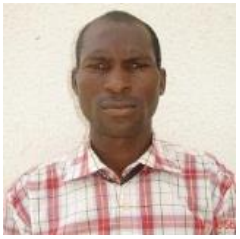

Tunji John Erinle is a Lecturer, Researcher, Professional and Certified Mechanical Engineer in the Department of Mechanical Engineering, The Federal Polytechnic, Ado-Ekiti, Nigeria. He holds a Master in Engineering (M. Eng.) degree in Mechanical Engineering. He is a member of many Professional Societies both National and International. Member of International Association of Engineers, Member of American Society of Mechanical Engineers and Member of Society of Automotive Engineers. His Scopus Author ID: 57214232158, Researcher ID: E-7752-2018 and Web of Science Researcher ID: AAL-3877-2020. The research interests are in the areas of Thermofluids, Renewable Energy, Machine Design, Tribology, Corrosion, Materials Mechanical Properties and Characterizations, Instrumentation \& Control System, Mechatronics and Robotics.

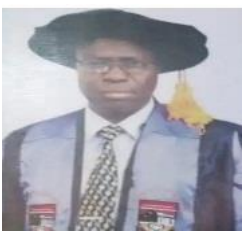

Dayo Hephzibah Oladebeye is a Chief Lecturer and Registered Mechanical Engineer in the Department of Mechanical Engineering, The Federal Polytechnic, Ado-Ekiti, Nigeria. He holds a Doctor of Philosophy ( $\mathrm{Ph}$. D) degree in Mechanical Engineering. He is a member of many Professional Societies both National and International. Member of International Association of Engineers. The research interests are in the areas of Renewable Energy, Machine Design, Mechatronics, Robotics, Instrumentation \& Control System, Industrial and Production Engineering.

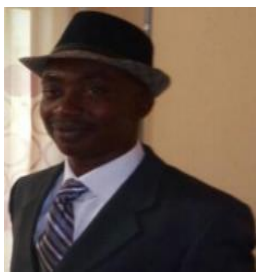

Ibrahim Bunmi Ademiloye is a Principal Technologist and Registered Electrical \& Electronics Engineer in the Department of Electrical and Electronics Engineering, The Federal Polytechnic, AdoEkiti, Nigeria. He is a member of many Professional Societies. The research interests are in the areas of Electrical, Electronics, Control System and Mechatronics. 